\section{REFERENCES}

1. Miterev G.A. Infantile infections control. Sbornik vazhneyshih ofitsialnyih i spravochnyih materialov po sanitarnyim $i$ protivoepidemicheskim voprosam v pomosch gossaninspektoru $i$ epidemiologu. Moscow, 1941, pp. 481-485. (In Russ.)

2. Manannikova N.V. Main tasks of children health protection in 1941 Voprosyi materinstva i mladenchestva. 1940, N 12, pp. 1-4. (In Russ.)

3. Manannikova N.V. Mother and child health care in the USSR Meditsinskaya sestra. 1942, vol. 1, N 11-12, pp. 16-19. (In Russ.)

4. Ershov G.F. Demographical consequences of the War in Molotov region. Mediko-sanitarnyie posledstviya voynyi i meropriyatiya po ih likvidatsii. Trudyi Vtoroy konferentsii (17-19 dekabrya 1946 g.). Moscow. 1948, vol. 1, pp. 12-15. (In Russ.)

5. Manannikova N.V. Infant health care in the USSR. Moscow, 1973, 302 p. (In Russ.)

6. Miterev G.A. In time of peace and war. Moscow, 1975, $255 \mathrm{p}$ (In Russ.)
7. Isupov V.A. Demographical catastrophes and creeses in Russia in the first half of the XX century. Novosibirsk, 2000, 244 p. (In Russ.)

8. Isupov V.A. The Victory main resourse. A human potential of West Siberia during World War II (1939-1945). Novosibirsk, 2008 , 378 p. (In Russ.)

9. Demographic modernization in Russia, 1900-2000. Moscow, 2006. 608 p. (In Russ.)

10. Mindich D.A. On a vital prescription ... Energiya promyish lennogo rosta. Velikaya Pobeda: lyudi, opyit, tehnika. Moscow, 2010, pp. 21-27. (In Russ.)

11. Bongaarts $J$., Sobotka T. A demographic explanation for the recent rise in European fertility. Population and development review, 2012, March, N 83-120, pp. 38-52.

12. Aralovets N.A. An urban family in Russia, 1927-1959. Tula, 2009, 304 p. (In Russ.)

Статья принята редакиией 09.07.2015

DOI: $10.15372 / \mathrm{HSS} 20150318$

УДК 94(47)»1941/45»

\title{
М.В. ШИЛОВСКИЙ
}

\section{СОВЕТСКИЕ АСЫ В ВЕЛИКОЙ ОТЕЧЕСТВЕННОЙ ВОЙНЕ 1941-1945 ГГ.} Часть 2

\author{
Михаил Викторович Шиловский, \\ д-р ист. наук, заведующий сектором, \\ Институт истории СО РАН, \\ РФ, 630090, Новосибирск, ул. Николаева, 8 , \\ e-mail: kapital@history.nsc.ru
}

\begin{abstract}
Статья основана на сведениях, собранных и систематизированных М.Ю. Быковым в справочнике «Асы Великой Отечественной. Самые результативные летчики 1941-1945 гг.» 2007 г., о 1114 летчиках-истребителях советских ВВС, участвовавших в Великой Отечественной войне. Эта элитарная группа анализируется с позиция участия в боевых действиях и количества сбитых фашистских самолетов. Устанавливаются типы отечественных истребителей и полученных от союзников по ленд-лизу, анализируется количество сбитых фашистских самолетов. Все поименованные в источнике родились в первой четверти XX в. и находились во время войны в возрасте до 40 лет. Их вклад в завоевание господства в воздухе составил 23974 индивидуально и 3315 коллективно сбитых самолетов противника, всего 27289 боевых машин (24,5 на каждого), или 48 \% от общего количества уничтоженных на советско-германском фронте. Отечественное производство стало материальной основой завоевания советскими ВВС господства в воздухе; незначительную часть самолетов, на которых воевали советские асы (2 \%), составили истребители, полученные по ленд-лизу.
\end{abstract}

Ключевые слова: Великая Отечественная война 1941-1945 г2., летчик-истребитель, ас, господство в воздухе, государственные награды, воинские звания, ВВС РККА, истребительный авиаполк, самолеты противника.

\section{M.V. SHILOVSKY}

\section{SOVIET ACE PILOTS IN THE GREAT PATRIOTIC WAR OF 1941-1945.}

Part 2

Mikhail V. Shilovsky, Doctor of Historical Sciences, Head of Department, Institute of History SB RAS, 8 Nikolaev Str., Novosibirsk, 630090, Russia e-mail: kapital@history.nsc.ru 
The article presents data on 1,114 fighter pilots of the Soviet Air Forces compiled and systematized in the reference book «Aces of the Great Patriotic War» by M.Yu. Bykov. The paper «The Most Successful Ace Pilots in 1941-1945» (2007) analyzes the elite group of ace pilots in terms of their age, military ranks, time of their participation in combat operations, a number of downed Nazi aircrafts, government awards. The author defines types of Soviet fighters as well as aircrafts supplied under Lend-Lease by the allies on the anti-Hitler coalition. All ace pilots mentioned in the reference book were born in the early XX century and during the war were younger than 40 years old. Their contribution to the air space conquest was 23,974 (individually) and 3,315 (collectively) shot down enemy planes, in total 27,289 combat vehicles ( 24.5 by each ace pilot), or $48 \%$ of the hostile aircrafts downed at the Soviet-German front. 579 of 1,114 aces were honored with the title of Hero of the Soviet Union, while 58 of them (every tenth) were awarded posthumously. Irretrievable losses in the group under study totaled 243 men (29\%) or about one third. At the beginning of the war the Soviet pilots flew I-15bis, I-16, I-153, MiG-3, LaGG-3 fighters. Since the summer of 1942 they had been replaced by Yak (Yak-1, -7, -9, -3) and La-5, 7 modifications. Domestic production provided the material basis for conquering air superiority by the Soviet Air Force. Only a small part ( $2 \%)$ of fighters used by Soviet aces in the aircraft fleet was supplied under Lend-Lease.

Key words: Great Patriotic War of 1941-1945, fighter pilot, ace, air supremacy, government awards, military ranks, Red Army Air Forces, fighter wing, number of aircraft downed individually and collectively (in the group).

Среди авиаторов были и кавалеры «солдатского» ордена Славы, учрежденного 8 ноября 1943 г. Хотя к тому времени среди пилотов рядовых, сержантов и старшин было немного, тем не менее, в статусе этой государственной награды специально оговаривалось, что ею «награждаются лица рядового и сержантского состава Красной Армии, а в авиации и лица, имеющие звание младшего лейтенанта, проявившие в боях за Советскую Родину славные подвиги храбрости, мужества и бесстрашия» [1, с. 75]. Всего орденом Славы 3-й степени из 1114 советских летчиков-истребителей, участвовавших в Великой Отечественной войне и занесенных в справочник «Асы Великой Отечественной. Самые результативные летчики 1941-1945 гг.» (M., 2007) [2], было награждено четверо, в том числе младший лейтенант Б.С. Дементеев, сержант, а впоследствии старший лейтенант, Герой Советского Сoюза М.В. Лусто и сержант (лейтенант), Герой Советского Союза С.В. Носов.

Несмотря на наличие приказов, регламентирующих награждение за воздушные победы 1942 и 1943 гг., анализ персональных данных из справочника показывает, что этот процесс осуществлялся стихийно и зависел от множества факторов, не указанных в источнике. Так, младший лейтенант Н.Ф. Кошельков, с октября 1943 по апрель 1944 г. сбивший лично 15 и в группе 3 самолета противника, был награжден орденом Боевого Красного Знамени, старший лейтенант В.И. Савин за 17 индивидуально и 2 в группе уничтоженных самолета с апреля по октябрь 1943 г. был награжден орденом Отечественной войны 1-й степени. Зато капитан П.С. Луговцов за 10 воздушных побед удостоился трех орденов Боевого Красного Знамени. Капитан А.С. Амелин за 17 лично сбитых самолетов был удостоен звания Героя Советского Союза и ордена Ленина, четырех орденов Боевого Красного Знамени, Отечественной войны 1-й и 2-й степени, трех орденов Красной Звезды, т. е. получил по ордену за каждый второй сбитый им самолет. По всей видимости, помимо количества сбитых фашистских самолетов, при составлении представлений на награждение во внимание принимались и другие факторы: от политико-морального состояния претендента на правительственную награду до службы в элитной (гвардейской) части, участия в крупной и победоносной стратегической операции.
С точки зрения послевоенных реалий фронтовые заслуги даже выдающихся летчиков-истребителей выглядели скромно. Например, А.И. Покрышкин удостоился: 22 декабря 1941 г. ордена Ленина, 22 апреля 1943 г. ордена Боевого Красного Знамени, 24 мая 1943 г. ордена Ленина и медали «Золотая Звезда» Героя Советского Союза, 18 июля 1943 ордена Боевого Красного Знамени, 22 августа 1943 г. второй медали «Золотая Звезда» Героя Советского Союза, 24 декабря 1943 г. ордена Боевого Красного Знамени, 19 августа 1944 г. третьей медали «Золотая Звезда» Героя Советского Союза, 6 апреля 1945 г. ордена Суворова 3-й степени, 29 мая 1945 г. ордена Суворова 2-й степени [3, с. 183].

Однако среди наиболее результативных летчиков-истребителей были и свои рекордсмены, добившиеся высоких результатов за сравнительно непродолжительные периоды участия в боевых действиях. Так, младший лейтенант Н.Д. Кудря (1921-1943) за три месяца боев в 1943 г. одержал 11 побед; младший лейтенант В.С. Конобаев (1921-1943) за пять месяцев в 1943 г. сбил индивидуально и в группе 20 самолетов; лейтенант С.В. Макаров (1919-1942) за 7 месяцев 1942 г. совершил 260 боевых вылетов и сбил в общей сложности 23 самолета противника.

Как известно, государственными наградами награждались летчики, прежде всего, за уничтоженные в воздухе и на земле вражеские самолеты. Всего на счету у 1114 респондентов их числится 23 974, т.е. примерно 20,6 на каждого. Уже за эти результаты каждый в изучаемой группе, согласно различного рода приказам, положениям и прочим инструкциям того времени, был достоин присвоения ему звания Героя Советского Союза. Еще 3315 фашистских самолетов летчики-асы сбили коллективно, т.е. примерно по три на каждого. В совокупности их боевой вклад в разгром люфтваффе составил 27289 машин (24,5 на каждого), или $48 \%$ от общего количества самолетов, уничтоженных на востоке, в боевых действиях против советских вооруженных сил.

Однако на войне боевые потери несли и советские ВBC. В недавнем прошлом о них старались не упоминать, за исключением фактов гибели наиболее выдающихся летчиков. Лишь в начале 1990-х гг. сообщили, что из общего ресурса самолетов (имевшихся к началу войны и поступивших на вооружение в ее ходе) в 
135,6 тыс. потери в ходе боевых действий составили 43,1 тыс. [4, с. 39]. Но не все пилоты при этом погибали. Так, А.И. Покрышкина сбивали дважды.

Тем не менее потери были, в изучаемой совокупности они составили 243 чел. (29\%), или примерно одна треть от общего количества в 1114 чел. Источник фиксирует следующие виды боевых потерь: сбиты в воздушном бою - 69 чел. $(28,4$ \% от общего количества погибших), не вернулись с боевого вылета - 91 $(37,9 \%)$, сбиты огнем с земли - 22 чел. (9\%). Всего боевые потери составили 182 чел. (82,7 \%). К ним можно отнести одного погибшего при таране самолета противника - старшего лейтенанта В.П. Цветкова (15 лично сбитых самолетов), погибшего 7 апреля 1945 г. при бомбардировке аэродрома базирования; трех раненых в воздушном бою и умерших после вынужденной посадки; двух пропавших без вести в плену; наконец, 31 погибшего в авиакатастрофах, в частности, летчиков, сбитых при перебазировании или в служебных командировках на транспортных Ли-2, где они были пассажирами. Таким образом, собственно боевые потери составили 220 военнослужащих ВВС РККА (90,5 \%).

Еще 23 летчика-истребителя ушли из жизни в силу целого комплекса привнесенных в войну причин, которые в журналах боевых действий и «похоронках» обтекаемо позиционировались как связанные с «исполнением служебных обязанностей». Так, «погиб 1 ноября 1944 г. в авиакатастрофе - разбился в тренировочном полете на Ла-7» Герой Советского Союза (дважды Героем стал посмертно) капитан А.Ф. Клубов (с. 283). Ненавязчиво упоминается еще один виновник катастрофы - новый истребитель Ла-7, который с апреля 1944 г. начал выпускаться серийно, «как один из основных наших истребителей в последний год войны» [5, с. 235].

Обстоятельства трагедии подробно воспроизводит однополчанин Клубова - Герой Советского Союза Г.Г. Голубев. Действительно, в ноябре 1944 г. на территории Польши осваивали полеты «на только что поступившей в истребительную авиацию новинке - самолете Ла-7 конструкции Лавочкина». После успешного полета «самолет Клубова коснулся грунтовой взлетно-посадочной полосы и побежал по ней. Под воздействием бокового ветра самолет почти незаметно стал уклоняться вправо, выкатился за пределы полосы и уже на малой скорости на глазах у всех словно бы споткнулся и... скапотировал. Вначале самолет стал на нос, задрав высоко кверху хвостовое оперение, мгновение постоял, словно раздумывая, в строго вертикальном положении, и как бы нехотя, медленно стал валиться на спину... Когда мы прибежали, было уже поздно. То, что мы увидели, отказывалось воспринимать наше сознание: голова Клубова была придавлена к земле левым бортом истребителя. Небольшая лужица крови... Причиной гибели капитана Клубова оказалась... небольшая канава, размытая ливневым дождем. Была она немного в стороне от взлетно-посадочной полосы, справа, скрытая травой. И надо было случиться такому, что одно из колес самолета Клубова на пробеге угодило именно в эту канаву... Нелепая случайность, которая обернулась трагедией. Она дорого обошлась нам. До сих пор сердцу больно от той тяжелой утраты. На боевом счету А. Клубова было уже более 40 сбитых самолетов противника» [6, с. 167-168].

К категории бытовых несчастных случаев отнесли смерть майора, Героя Советского Союза А.И. Тимошенко, «зарубленного винтом самолета на аэродроме» в марте 1945 г.; еще одного Героя, лейтенанта И.Н. Сержантова, отравившегося техническим спиртом в 22-летнем возрасте; трех летчиков, покончивших с жизнью посредством самоубийства; умершего от инфекционного заболевания лейтенанта Л.Ф. Кравчука. Война уничтожала и калечила ее участников разными способами. Прошедший Испанию и большую часть Великой Отечественной войны, Герой Советского Союза подполковник Г.Н. Прокопенко во время боевого вылета в июле 1944 г. был сбит стрелком пикирующего бомбардировщика Пе-2. Незавидной была участь подбитых над линией фронта. Например, совершивший вынужденную посадку в октябре 1943 г. лейтенант Н.Т. Лисицын был убит на земле. Из строя выбывали, получив инвалидность подобно Н.Г. Пахомову, в результате ранения в мае 1945 г. потерявшего ногу, или майора П.С. Шемендюка, тяжело раненого в воздушном бою в июле 1943 г. и потерявшего руку. Еще одной причиной могло стать попадание в плен (и возвращение из него уже после окончания войны).

Как отмечалось выше, все представители изучаемой совокупности во время войны находились в возрасте до 40 лет. По времени приобщения к боевым действиям их условно можно разделить на три группы. Еще до июня 1941 г. 68 летчиков (6,9%) приняли участие в локальных военных конфликтах: Гражданской войне в Испании 1936-1939 гг. - 5 чел.; у озера Хасан (1938 г.) - 5 чел.; на Халхин-Голе (1939 г.) - 14 чел.; в Японо-китайской войне 1938-1940 гг. - 2 чел. и Советско-финляндской войне 1939-1940 гг. - 42 чел. Так, майор М.А. Федосеев, погибший в марте 1942 г., в Испании лично сбил 5 самолетов противника; подполковник (в 1939 г. - капитан) А.Д. Якименко за 7 сбитых японских самолета 29 августа 1939 г. удостоился звания Героя Советского Союза.

Примерно треть из 1114 истребителей боевой опыт приобрели после начала Великой Отечественной войны. Поэтому они, как правило, занимали нижние ступеньки в системе персональных званий командного состава РККА. Подвижки за время ведения боевых действий были, но не такие существенные, как в сухопутных войсках. Например, Е.Д. Андреев за 1942 г. и за 10 месяцев 1943 г. прошел путь от сержанта до младшего лейтенанта. Больше всего из сержантов или младших лейтенантов поднялись до капитанов - более 50 чел. Двое стали генералами. Причем, майор, командир истребительной авиадивизии Е.Я. Савицкий, начавший воевать в мае 1942 г., войну закончил генерал-лейтенантом, командиром истребительного авиакорпуса; совершивший первый боевой вылет в июле 1941 г. капитан Г.В. Зимин закончил войну генерал- 
майором, командиром истребительной авиадивизии.

Сопоставление воинских званий летчиков исследуемой группы на начало их участия непосредственно в боевых действиях (июнь 1941 - первая половина 1943 г.) и на конец войны или гибели в 1944 г. позволяет говорить об определенных подвижках в этом вопросе. В первом случае в справочнике имеются сведения на 800 чел. Низшее воинское звание (сентябрь 1942 г.) имел красноармеец К.В. Сухов, впоследствии ставший капитаном, Героем Советского Союза, лично сбивший 22 самолета. Самое высокое звание имели 5 майоров. Остальных можно сгруппировать следующим образом: младший командный состав (сержант, старший сержант, старшина) - 276 (34,5 \%), лейтенанты (от младшего до старшего) - 472 (59 \%), капитаны и майоры - $38(4,7 \%)$.

Еще одну немногочисленную группу представляли политработники: 3 политрука, 7 старших политруков и 3 батальонных комиссара. Их появление связано с учреждением в начале Великой Отечественной войны (16 июля 1941 г.) института военных комиссаров, а в эскадрильях - политруков; эти должности существовали до ноября 1942 г. На них возлагалась задача обеспечивать усиление партийного влияния в вооруженных силах, оказывать всестороннюю помощь командирам в боевом и политическом руководстве военнослужащими. В Военно-воздушных силах значительная часть политработников «выдвигалась» (по терминологии тех лет) из числа летчиков-коммунистов, которые совершали боевые вылеты. «Летающие политруки» пользовались авторитетом среди личного состава авиационно-истребительных частей, а после ликвидации этого института они успешно служили на строевых должностях. Так, батальонный комиссар В.А. Меркушев к лету 1944 г. стал подполковником, за 24 лично сбитых самолета ему в 1943 г. присвоили звание Героя Советского Союза, наградили двумя орденами Ленина. Бывший старший политрук Б.М. Васильев войну закончил подполковником, Героем Coветского Союза.

В 1942 г. во фронтовые истребительные полки пришли выпускники и инструкторы летных училищ. В первой половине 1943 г. в преддверии битвы на Курской дуге истребительные части воздушных армий в последний раз массировано получили пополнение из сержантов и младших лейтенантов, после чего фронтовые формирования ВВС пополнялись за счет прошедших курс лечения в госпиталях выпускников и инструкторов летных училищ.

На заключительном этапе войны (вторая половина 1943 - май 1945 г.) из 1001 летчика-истребителя самую многочисленную категорию составили капитаны - 341 чел. (34 \%) и майоры - 316 чел. (31,5 \%). За ними шли лейтенанты - 262 чел. (26 \%). Причем количество младших лейтенантов сократилась со 198 на первом этапе до 22 на втором. Зато появились штабофицеры (подполковники и полковники) - 73 чел. и два поименованных выше генерала. Казалось бы, должна исчезнуть категория рядовых и сержантов, посколь- ку выпущенные из летных училищ и адаптировавшиеся к фронтовой обстановке сержанты должны были стать офицерами. Однако среди 1001 аса числилось 4 рядовых, 2 сержанта и один старший сержант, всего 7 военнослужащих. Что касается сержантов, то их наличие объясняется, по всей видимости, отсутствием шансов на приобщение к офицерской корпорации. Так, сержант И.Ф. Луговенко, прибывший во фронтовой 866-й истребительный авиаполк в октябре 1942 г. и сбивший лично 10 самолетов противника, в звании сержанта погиб в воздушном бою 8 февраля 1943 г. Сержант И.Ф. Сычев, начавший воевать в сентябре 1942 г., встретил день Победы в таком же звании, хотя на его счету насчитывалось 13 побед.

Что касается рядовых, то ими стали летчики-офицеры, осужденные военным трибуналом, как правило, за уголовные преступления и разжалованные в рядовые. Среди таковых следует назвать младшего лейтенанта В.В. Валуева, совершившего 150 боевых вылетов и одержавшего 21 победу; старшего лейтенанта А.А. Дьячкова, сбившего 31 самолет противника. Ему удалось к началу 1945 г. стать сержантом, удостоиться посмертно в 1946 г. звания Героя Советского Союза. Подполковник Н.А. Козлов был понижен в звании до лейтенанта, что не помешало ему сбить 23 самолета противника, стать Героем Советского Союза, кавалером орденов Ленина, Боевого Красного Знамени (2), Александра Невского, Отечественной войны 1-й степени (2), Красной Звезды (3).

В источнике не указано, за какие провинности боевые офицеры были осуждены и разжалованы в рядовые; они продолжали участвовать в боевых действиях и регулярно пересекали линию фронта. По всей видимости, содействовала этому обстановка фронтовой повседневности летчиков-истребителей. В отличие от пехотинцев, танкистов, артиллеристов, большей частью находившихся на передовой, авиаторы располагались при полевых аэродромах своих частей на удалении от передовой. Многие из них, согласно воспоминаниям, снимали жилье в частном секторе. Поскольку денежное содержание не выдавалось на руки, а перечислялось либо родственникам, либо на персональный счет в сберегательной кассе, источником наличных денег могли быть премии за сбитые самолеты или за осуществленные вылеты, иногда достигавшие нескольких тысяч рублей. К тому же во время вынужденного бездействия из-за плохой погоды имели место случаи изготовления суррогатных спиртных напитков, типа ликера «Шасси» (из художественного фильма «Хроника пикирующего бомбардировщика» - 1968, режиссер Н.Б. Бирман). На этом фоне, как отмечалось применительно к ситуации августа 1942 г., в 16-м гвардейском истребительном авиаполку «пошли повальные нарушения воинской дисциплины, связанные в основном с «расслаблением» спиртными напитками летного и технического состава». Для наведения порядка командир части 23 августа подписал приказ, один из пунктов которого был посвящен нашему прославленному земляку: «За неоднократные нарушения советско-во- 
инской дисциплины, пьянства с дебошем и оскорблением старших командиров зам. командира эскадрильи капитана Покрышкина отдать под суд трибунала» $[7$, c. 605-607]. Конфликт замяли, но сам по себе случай характерный.

Обобщая сказанное относительно группы советских асов, следует отметить, что ее формирование стало прямым следствием индустриального развития Советского Союза в предвоенное десятилетие. Как отдельная социальная группа рассматриваемая совокупность отличалась не только молодостью, но и пролетарским происхождением, наличием неполного среднего образования (4-8 классов) и предварительной подготовкой в системе аэроклубов. В них курсанты без отрыва от основной работы или учебы выполняли прыжки с парашютом, учились летать на планерах, проходили первичную летнюю подготовку на самолетах У-2 (По-2). Проходившим подготовку в системе Осоавихима и Гражданского воздушного флота полагалась стипендия 250 руб. в месяц, к учебе допускались лица, «имеющие общее образование не ниже 7 классов средней школы» [8, с. 147, 149]. В Новосибирск таким учебным заведением стала открытая здесь в 1930 г. 1-я Сибирская школа пилотов Осоавиахима, подготовившая в предвоенный период 1200 летчиков [9, с. 54].

Таким образом, анализ данных справочника М.Ю. Быкова о 1114 советских воздушных бойцах Великой Отечественной войны 1941-1945 гг., одержавших от 10 и более побед, т.е. асов - по западной терминологии, позволяет уточнить качественные показатели эффективности ведения боевых действий в воздухе. Все поименованные в источнике родились в первой четверти XX в. (1905-1924 гг.). Более половины наших выдающихся летчиков-истребителей к маю 1945 г. имели возраст 23-27 лет, а все они вместе взятые находились в возрасте до 40 лет. Вклад представителей изучаемой группы в завоевание господства в воздухе составил 23974 сбитых индивидуально и 3315 коллективно самолетов противника, всего 27289 машин (24,5 на каждого), или 48 \% от общего количества уничтоженных на советско-германском фронте самолетов противника. В свою очередь, безвозвратные потери советских асов составили 243 чел. (29\% от их числа), в том числе боевые 182 чел. По времени включения в боевые действия представители изучаемой группы условно относились к трем группам: примерно треть начала воевать 22 июня 1941 г., из них 68 летчиков принимали участие в войнах и военных конфликтах в Испании, Халхин-Голе, на оз. Хасан, в Японо-китайской войне 1938-1940 гг., Советско-финляндской войне 1939-1940 гг. Треть приобрела опыт боевых действий в 1941 - первой половине 1942 г. Еще одну треть составили выпускники и инструкторы авиационных училищ, направленные во фронтовые части во второй половине 1942 - первой половине 1943 г. в преддверии битвы на Курской дуге. Войну начинали сержанты (39,5 \% от общего количества) и лейтенанты (59 \%), а заканчивали капитаны (34 \%), майоры
(31,5\%) и лейтенанты (26 \%). Из 1114 летчиков-истребителей 579 стали Героями Советского Союза, в том числе 58 (каждый десятый) посмертно. Вклад в «корпорации» истребителей будет выглядеть весомее, если учесть, что всего за время Великой Отечественной Героями стали 810 летчиков-истребителей. Следовательно, представители изучаемой группы в ней абсолютно преобладали - их доля составила 73 \%.

Войну советские летчики встретили на истребителях И-15 бис, И-16, И-153, МиГ-3, ЛаГГ-3. С лета 1942 г. им на смену пришли модификации ЯК (Як-1, $7,9,3)$ и Ла-5, 7. Отечественное производство стало материальной базой для завоевания советскими ВВС господства в воздухе. Незначительную часть (2 \%) самолетов, на которых воевали советские асы, составили истребители, полученные по ленд-лизу от США и Великобритании.

\section{СПИСОК ЛИТЕРАТУРЫ}

1. Сборник законодательных актов о государственных наградах СССР. М.: Известия, 1984. 303 с

2. Быков М.Ю. Асы Великой Отечественной. Самые результативные летчики 1941-1945 гг. М.: Яуза; Эксмо, 2007. 736 с.

3. Левобережье Новосибирска. Страницы истории. Новосибирск, 1999. 504 с.

4. Кривошеев Г.Ф. Война брони и моторов // Военно-исторический журнал. 1991. № 4. С. 36-42.

5. Шавров В.Б. История конструкций самолетов в СССР 1938 1950 гг. М.: Машиностроение, 1988. 568 с.

6. Голубев Г.Г. В паре с «Сотым». М.: ДОСААФ, 1974. 245 с.

7. Табаченко А.И. Покрышкинский авиаполк. «Нелакированные» боевые хроники. 16-й гвардейский истребительный авиационный полк в боях с люфтваффе. 1943-1945. М., 2012. 751 с.

8. Семенов И.М. Век полета. История аэропорта Курган. Курган, 2013. Ч. $1.476 \mathrm{c}$.

9. Дворянчикова Р.И. Аэроклуб Новосибирский // Энциклопедия Новосибирска. Новосибирск, 2003. С. 54-55.

\section{REFERENCES}

1. Collected legislative acts on state decorations in the USSR. Moscow: Publishing House "Izvestiya", 1984, 303 p. (In Russ.)

2. Bykov M.Yu. Aces of the Great Patriotic War. The most productive pilots, 1941-1945: Reference. M.: Yauza; Eksmo, 2007, 192 p. (In Russ.)

3. Left Bank Area of Novosibirsk. Pages of History. Novosibirsk, 1999, 504 p. (In Russ.)

4. Krivosheev G.F. War of Armor and Motors. Voenno-Istoricheskiy Zhurnal. 1991, no 4, p. 36-42. (In Russ.)

5. Shavrov V.B. History of Aircraft Design in the USSR, 19381950. Moscow: Mashinostroyeniye, 1988, 568 p. (In Russ.)

6. Golubev G.G. Paired with "The Hundredth". Moscow: DOSAAF, 1974, 245 p. (In Russ.)

7. Tabachenko A.I. Pokryshkin Fighter Wing. Unvarnished Combat Chronicles. $16^{\text {th }}$ Guards Fighter Wing in Battles with Luftwaffe. Moscow, 2012, 751 p. (In Russ.)

8. Semyonov I.M. Century of Flights. History of the Kurgan Airport. Kurgan, 2013, part 1, 476 p. (In Russ.)

9. Dvoryanchikova R.I. Novosibirsk Flying Club. Encyclopedia of Novosibirsk. Novosibirsk, 2003, pp. 54-55. (In Russ.)

Статья принята редакичей 03.08.2015 